\title{
加工助剂の進歩と動向
}

\author{
秋 葉 光 雄*.大 貫 ${ }^{*}$ 毅
}

\section{Development and Trend of Processing Aids}

Mitsuo AKIBA ${ }^{1 *}$, Takeshi OHNUKI ${ }^{2}{ }^{1}$; AKIBA Reseach, Japan 2999-3 Ozone, Tsukuba, Ibaraki 300-3253, Japan, 2; Kawaguchi Chemical Industry Corporation, Japan Research and Development Division, 4-6-42 Ryoke, Kawaguchi, Saitama 332-0004, Japan)

This paper describes the role, fundamental classification, and functionality of processing aids. The recent technical trends and future views of processing aids are also described in detail.

Key Words : Processing Aid, Homogenizer, Multifunctional Additive, Mold Releasing Agent, Lubricant

\section{1.は じめに}

一般のゴム製品は，原料ゴムのみならず各種ゴム用配合 剤を含んでいる，さらに，たとえば自動車タイヤ，工業用 ベルトなどは，補強性抢よび形状保持を目的とする金属， 繊維などの副資材も含む一種の複合体である。その製造工 程は混合 (配合) $\rightarrow$ 成形 $\rightarrow$ 加硫の基本工程を経て製品化され る. 最近の加工助剂に関してはすでにいくつかの成書や総 説が報告されている ${ }^{1-6)}$.

各種配合剤の中で，加工性を考慮して配合される配合剤 の総称を, 加工剤(Processing Agents) といっている. 歴 史的には，19世紀後半の脂肪酸，オイル，ガム，タール， 樹脂などの使用が最初である。一方，O'Connorが加工性 に関与する配合剤を解説しており, 素練り促進剤, プロセ ス油, 可塑剤, 炭化水素樹脂, 滑剤, 低分子量ポリエチレ ン, 脂肪酸, 加硫植物油(サブ), 再生ゴムなどのほかに脂 肪酸の誘導体(エステル，金属塩，アミドなど)に分類して いる ${ }^{7)}$ ままた，加工助剤 (Processing Aids) は加工郕に含 有されるが，「その使用量は比較的に少なく( $0.5 \sim 5 \mathrm{phr})$, 加工性のみ改良して基本的な加硫物性にはほとんど影響し ない配合剤」と定義したKrichhoffの解釈に妥当性があり，

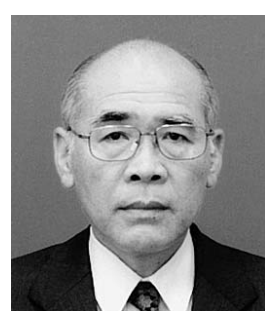

秋葉 光雄 ; アキバリサーチ ( くば市大曽根 2999-3) 所長. 工博理博. 昭和 55 年, 筑波大学大学院博士課程修了. 同年(財) 化学品検査協会入社. 専門はゴム材料化学, 研究部会幹事.
現在ではそれがほぼ認知されている.

\section{2. 加工助剤の分類と役割}

加工助剂は加工工程の向上に寄与し, しゃく解剤, 均質 化剂, 分散剂, 滑剂, 粘着付与剂, 内部離型剂等に分類で きる。

しゃく解剤は素練り促進剤とも呼ばれ，天然ゴムの粘度 を下げ，塑性を付与するために用いられる. ビス $(O$-ベン ズアミドフェニル) ジスルフィドまたはその亜鉛塩が主流 であり，活性成分としてある種の金属錯体を含有するもの が多い．また，ゴムへ素早く拡散するようにある種の分散 剤成分を添加して調製されたものもある，その他に脂肪酸 亜鉛塩はゴムの粘度を下げる作用が強いことから，物理的 なしゃく解剤といわれている.

均質化剂はゴムブレンドの均質化に寄与し, 異種ゴム間 の相溶性を高める必要性から相溶性の異なる幾つかの樹脂 類や低分子量ポリマーからなる複合物である場合が多い. また，樹脂類は粘着付与剂にもなり，配合ゴムとロール間 の滑りによるバギングを防止する効果がある.

滑剂は, 高級脂肪酸や脂肪酸金属塩, 脂肪酸エステル, 脂肪酸アミド等の脂肪酸誘導体等があり, 種類によって効

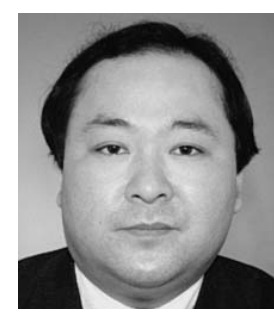

大貫 毅 ; 川口化学工業(株)(† 332-0004 川口 市領家 4-6-42) 研究開発部高分子加工 $G$ 副主 査. 平成 3 年, 埼玉工業大学工学部環境工学 科卒業. 同年, 川口化学工業株式会社入社. 専門は有機ゴム薬品全般。 
果の差があるものの，分散剂や潤滑剂 (流動性向上)，内部 離型剂としての機能も包含する．尚，滑剤の主流は加硫後 の最終製品の要求特性に対する影響が比較的少なく，その 効果がオールマイティーであることから脂肪酸エステル系 であると考える。さらに市販されている滑剤は，2 種類ま たはそれ以上の滑剤成分の混合品である場合も多く，その ほかに形状やハンドリングの関係から無機フィラーも含有 する複合型加工助剂であることもまれではない。

加工助剤の使用にあたって，その実用におけるメリット を表 1 に示すが，ゴム製品の生産性向上のみならず，品質 の改良，不良率の低下にも寄与するといえる。

また，最近では加工性に関するトラブルへの事後対策で はなく，配合設計の段階で加工助剤の必要性の有無を設定 することが一般的となっている。また，各種加工工程に要 求される特性を考慮して特殊に調製されている加工助剤で あるが，その主要成分を分類したおのおのについて，期待 される効果を表 2 に示した5).

次に各種加工助剂成分の基本的作用を概説する.

\section{1 高級脂肪酸系}

一般的には飽和または不飽和の直鎖アルキル基で， $\mathrm{C}_{12}$ $\sim \mathrm{C}_{30}$ 程度のものが, 分散剂, 滑剂, 離型剂として作用す る。ゴムおよびプラスチック(主として PVC)の滑剤とし ては，ステアリン酸 $\left[\mathrm{CH}_{3}\left(\mathrm{CH}_{2}\right)_{16} \mathrm{COOH}\right]$ がその代表であ る。工業用のステアリン酸は牛脂を原料としており，パル ミチン酸，オレイン酸も含有している。ゴム用には高純度 品がゴムとの相溶性, 加工性から良好といえる，化学的に は長鎖アルキル基の非極性部分と，カルボン酸基の極性部

表 1 加工助剤の有効性

\begin{tabular}{l|c|c}
\hline & 生産性 & 品質 \\
\hline フィラーの分散改良 & & $\bigcirc$ \\
$\begin{array}{l}\text { 混練時間の短縮 } \\
\text { 動カエネルギーの削減 }\end{array}$ & $\bigcirc$ & \\
ロール加工性の改善 & $\bigcirc$ & $\bigcirc$ \\
押出速度のアップ & $\bigcirc$ & \\
発熱性の低減 & $\bigcirc$ & $\bigcirc$ \\
ダイスウェルの減少 & $\bigcirc$ & $\bigcirc$ \\
圧延性の改良 & $\bigcirc$ & $\bigcirc$ \\
射出時間の短縮 & $\bigcirc$ & $\bigcirc$ \\
容易な成形性 & $\bigcirc$ & $\bigcirc$ \\
モールド離型性の向上 & $\bigcirc$ & \\
外観改善 & & $\bigcirc$ \\
\hline
\end{tabular}

\section{表 2 加工助剤期待される効果}

\begin{tabular}{|c|c|}
\hline しゃく解剤 & : ベースポリマーの粘度レベルを合わせる \\
\hline 口分 散 剂 & : 補強剤, 充てん剂の分散を向上し, 粘度を下げる \\
\hline 口潤 滑 剂 & : ゴム配合物の流れ性を改善する \\
\hline 口均 質 剂 & $\begin{array}{l}\text { : 異種ゴム間の相溶性に寄与し, 均質なブレンド } \\
\text { ゴムを得る }\end{array}$ \\
\hline 着付与剂 & $\begin{array}{l}\text { : ゴム配合物に適度な粘着性を付与し, 張り合わ } \\
\text { せを容易にする }\end{array}$ \\
\hline 補強用樹脂 & : ゴム配合物の物性を大きく変えずに硬さを増す \\
\hline
\end{tabular}

分を有する両性化学構造物質で, 各種ゴムに使用される.

\section{2 脂肪酸エステル系}

脂肪酸とアルコールによるエステル化反応物である．脂 肪酸，アルコールの違いやエステル化度の限定もあり，品 種が多い. 使用量も多く, はん用タイプの加工助剤である.

特徵としてはゴムコンパウンドへの軟化作用が少なく, エステル化により化学的に中性であることから, 加硫物性, 加硫速度に対する影響がほとんどなく，内部滑性的である ことから, 分散改善, 混練り時の配合内部の摩擦低減の効 果が得られる. 各種ゴムに使用されているが，一般的にエ ステル化度の高いタイプは, 高飽和ゴムである特殊ゴムに, 低エステル化度のタイプは，はん用ジエン系ゴムに使用さ れている．比較的分子量の小さい低エステル化夕イプは外 部滑性に優位性があり，押出し性または金型への流動性が 良好である. しかし, 加硫への活性作用があり, 耐スコー チ性を阻害することから，使用量の注意が必要である。

\section{3 脂肪酸金属系}

RCOOMタイプにはナトリウム $(\mathrm{Na})$ ，カリウム $(\mathrm{K})$ 塩が あり, 界面活性剂, 带電防止剂, 滑剂, 粘着防止剂として 有効である。ただし，化学的性質から水溶液の状態で使用 される場合が多く，固形ゴムの配合剤としてはあまり使わ れない。固形ゴムの加工助剤成分には主に $(\mathrm{RCOO})_{\mathrm{n}} \mathrm{M}$ 夕 イプが使用される。(RCOO) ${ }_{\mathrm{n}} \mathrm{M}$ タイプの金属には，亜鉛 $(\mathrm{Zn})$, カルシウム $(\mathrm{Ca})$, すず $(\mathrm{Sn})$, マグネシウム $(\mathrm{Mg})$, アルミニウム $(\mathrm{Al})$, 鉛 $(\mathrm{Pb})$, バリウム $(\mathrm{Ba})$ などがあるが, 安全衛生またはコストの関係から, 亜鉛, カルシウムが加 工助剂成分に使用されている。

\section{4 脂肪酸アミド系}

$\mathrm{RCONH}_{2},(\mathrm{RCO})_{2} \mathrm{NH},(\mathrm{RCO})_{3} \mathrm{~N}$ があるが，ゴム・プ ラスチック用に使用されているタイプは $\mathrm{RCONH}_{2}$ の第一 アミドである，脂肪酸種でステアリルアミド，パルミチル アミド，オレイルアミドのほかにステアリン酸ではビスタ イプ(メチルやエチル基)もある。外部滑性に優れ，ゴム・ プラスチックには滑剤，スリップ剂，ブロッキング防止剤 として使用される。しかし，その効果はブルーミングを利 用したものであり，多量添加は加硫ゴム表面の美観や金型 污染を引き起こす可能性もあるので, 注意が必要である.

\section{5 炭化水素系}

ゴム用耐オゾン剤のパラフィン，マイクロクリスタリン ワックスは外部滑性に有効で, 本来は加工助剤ではないが, 加工助剤の一成分として混合されている。

\section{6 アルコール系}

脂肪アルコール (セチル，ステアリル)，多価アルコール などは, PVC等のプラスチックの滑剤に利用されている が，ゴム用加工助剤として単独で用いられることはあまり ない.しかし, 脂肪アルコールは含ハロゲンゴム (ACM, $\mathrm{CO}, \mathrm{ECO}) に は$ 外部滑性を付与し，例えばロール付着防 
止にもなる。

\section{7 フッ素含有系}

加工助剤 (滑剂) の主流は脂肪酸誘導体であるが，含ハロ ゲン系または特殊ゴムの使用量増加から, オールマイティ 一加工助剤とともに特殊タイプのフッ素含有加工助剤も上 市されている。

\section{8 シリコーン含有系}

フッ素系と同様に外部滑性に有効で, 流動性および加工 機とのはく離効果がある．ポリオルガノシロキサンと有機 炭化水素化合物からなる，オルガノシリコーン共重合体心゙ ースの加工助剤, また, 市販品にはストラクトール NS180, WB280などがある.

\section{9 炭化水素樹脂系}

滑性機能を主体とする加工助剤とは若干異なる，ゴムブ レンドにおける均質化剤 (Homogenizing Agents)として 作用する成分である。例えば非極性ゴム/極性ゴムなど異 種ゴムのブレンドに使用し，その相溶性を向上させて均質 化を図る。プラスチックにみられる相溶化剤に近似した作 用を有する。

\subsection{0 その他}

加工助剤ではないが，本来の機能 (一次)のほかに二次ま たは三次に加工性の改良を有する配合剂, 多機能添加剂 (Multifunctional Additives)がある.アミンブリッジアミ ド $(\mathrm{ABA}), \mathrm{CR}$ のアミン加硫剤であるが，熱分解によって 生成する脂肪酸による流動, 離型性の付与が得られる.

\section{3. 最近の技術動向}

大貫は図 1 に示す2-トリアルコキシシリル-1,3-ブタジエ ンの重合体(1) からなるゴム用加工助剂を開発した ${ }^{8)}$ 。こ れはシリカ配合において粘度上昇を抑制し，物性に影響を 与えなかった。

また，彼は図 2 に示すデシルトリアルコキシシラン (2) およびシクロヘキシルアルキルジアルコキシシラン (3) か らなるゴム用加工助剤を開発した ${ }^{9)}$ 。これはシリカ配合の 加工性の改善と同時に加硫時の金型離型性も改善する機能 を備えている。

最近Menting らは従来のゴム成形金型の離型剤の問題 点を指摘した後，半永久金型離型剂の特徵とそれによる生 産性向上について報告している ${ }^{10)}$ 。従来の金型離型剤で

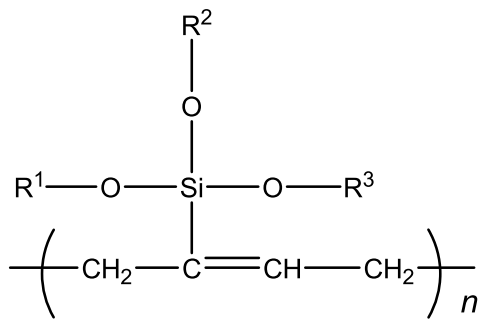

図 1 ブタジエン重合体加工助剂

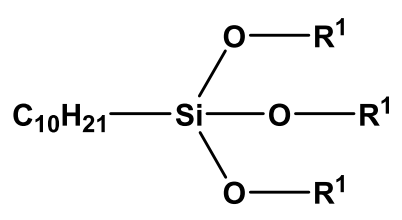

(2)

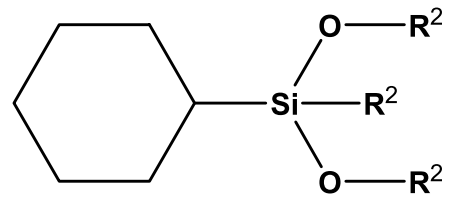

図 2 シラン加工助剤

ある油脂やワックスは安価であるが，金型に均一に塗布す ることが難しく，また，溶剤のVOCの問題があった。シ リコーンエマルションには金型污染の問題があり，フロー クラックの加工欠陥の問題もあった。半永久金型離型剤に は，低VOCの溶剤を用いた溶剂型とVOCを含まない水系 型があり,これらは金型の污染物を蓄積しない特徵がある. 最近の離型剤, PERMALESE 90 は $130{ }^{\circ} \mathrm{C}$ 以上では 30 秒以 下で硬化し, 通常の工業的生産では 50 サイクル, 時には 80 〜 100 サイクル金型離型を維持することによって生産性 が向上した。また，すでに離型剤の最近の動向については 秋葉の総説が報告されている11).

また，Jurkowskaらより NR/BRゴムの性質に及ぼすフ ッ素含有滑剂 (K29)の影響が報告された ${ }^{12}$ ）。この滑剂 K29 は $0.5 \mathrm{wt} \%$ 量でコンパウンドの粘度を低下させ，金型内 のコンパウンドの流動性を改善した。 また，加硫ゴムの機 能的性質は低下せず, 耐摩耗性および疲れ強さは増大した。 このように滑剂 K 29 はNR/BR ゴム用の多機能添加剤とし て作用する。

すでに多機能配合剤については秋葉の総説が報告されて いる13).

多環芳香族炭化水素の濃度が高い伸展油は，2009年 12 月までに禁止されるのであるが，2007年，Dasguptaらは 油およびゴム工業での対策の検討結果を報告している ${ }^{14)}$. この報告では 10 種類の天然由来油および 6 種類の石油べ ース油の化学および物理的性質を特性化している。また， 天然ゴムベーストラックタイヤトレッドキャップ配合物中 のこれらのプロセス油の影響についても検討し，いくつか の天然由来の油はより良好な加工性, 重合体-充てん剂相 互作用および分散性を示すと述べている.

さらに，JonesらはH-NBR コンパウンド加工改良のため のコンパウンディング手法についても報告している ${ }^{15)}$.

\section{4. 将来の展望}

現実的な立場より, 加工助剂の開発を志向した配合技術 の進歩について述べた。今日, 熱可塑性エラストマーを始 め多種多様なエラストマーが合成され, それらの加工を容 易にする加工助剤には追風が吹いている。また，コスト低 


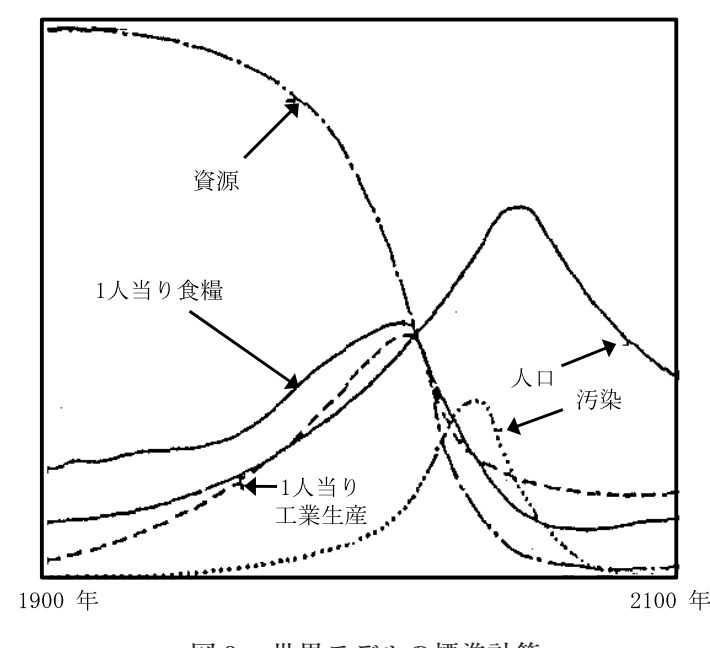

図 3 世界モデルの標準計算

減や加工時間の短縮から多種の加工剤が使用されている.

加工助剂の今後の方向として，コスト面から安価な加工 助剂が合成されよう．図 3 に示すように資源問題から天然 物も加工助剤として見直される。また，環境問題から有害 性のない加工助剤が上市されよう。

一方, 配合剂としては多機能·高性能の加工助剂が望ま れ，その方向に進むものと推定される．また，今後も内部 加工助剤と外部加工助剂として, 従来通りの使い方でゴム に配合されるが，いずれの場合も少量配合の方向に向かう であろう。

いずれにしても，資源問題，環境問題，リサイクル問題 を考虑した使い方が重要となろう。

表3にゴム加工の推移と未来像を示したが，アンダーラ インを付した技術が実用化されるようになると配合技術も かなり変革していくものと思われる，さらに，配合剤の中 でも加工助剤は反応型，マルチ機能㧍よび高性能·高機能. 多機能の方向に向かって行くものと予想される.

\section{References}

1 ) Akiba, M.; Numaho, I.: "Gomu Elastomer no Kakoujozai", Gijutsu Jouho Kyokai, Tokyo, Chapter 2, 3 (2000)

2 ) Numaho, I.; Akiba, M.: Polymer Digest, 54 (6), 93 (2002) ; ibid, 54 (7), 107 (2002)

3 ) Hoei, Y.: Nippon Gomu Kyokaishi, 79, 323 (2006)

4) Mukai, U.: 136th Gomu Gijutsu Symposium Text, Nippon Gomu Kyokai, 9 (2007)

5) Igarashi, N.: 136th Gomu Gijutsu Symposium Text, Nippon Gomu Kyokai, 15 (2007)

6 ) Nishizawa, H.: Polyfile, 45 (4), 68 (2008)

7 ) O'Connor, F. M.; Slinger, J. L.: Rubber World, 187, 19 (1982)

8 ) Ohnuki, T.: Jpn. Kokai Tokkyo Koho 2003-213047 (2003)

9 ) Ohnuki, T.: Jpn. Kokai Tokkyo Koho 2005-281656 (2005)

10) Menting, K.; Hensel, M.: Paper presented at the 170th meeting of Rubber Division, American Chemical Society, 10 (2006)

11) Akiba, M.: 119th Gomu Gizutsu Symposium Text, Nippon Gomu Kyokai, 35 (2005)

12) Jurkowska, B.; Jurkowski, S.; Nadolng, K.: Eur. Polym. J., 42, 1676 (2000)

13) Akiba, M.: Polymer Digest, 52 (12), 17 (2000)

14) Dasgupta, S.; Agrawal, S.; Bandyopadhyay, S.: Polym. Test., 26, 489 (2007)

15) Jones, M.; Anderson, A.: Rubber World, 236, 30 (2007)

\section{日本語表記参考文献}

1 ）秋葉光雄, 沼保勇：ゴム・エラストマーの加工助剤, 技術情報 協会，東京 $(2000)$

2 ）沼保勇，秋葉光雄：ポリマーダイジェスト，54(6)，93 (2002) ; ibid, 54 (7)， 107 (2002)

3 ）宝永嘉男：日本ゴム協会誌，79，323（2006）

4 ）迎宇宙：136 回ゴム技術シンポジウムテキスト, 日本ゴム協会, 9 (2007)

5 ）五十嵐信夫：136回ゴム技術シンポジウムテキスト，日本ゴム 協会, 15 (2007)

6 ）西澤仁：ポリファイル，45(4)，68 (2008)

8 ) 大貫毅：特開 2003-213047 (2003)

9 ）大貫毅：特開 2005-281656 (2005)

11）秋葉光雄：119回ゴム技術シンポジウムテキスト，日本ゴム協 会，35 (2005)

13）秋葉光雄：ポリマーダイジェスト，52（12），17 (2000)

表 3 ゴム加工の推移と未来像

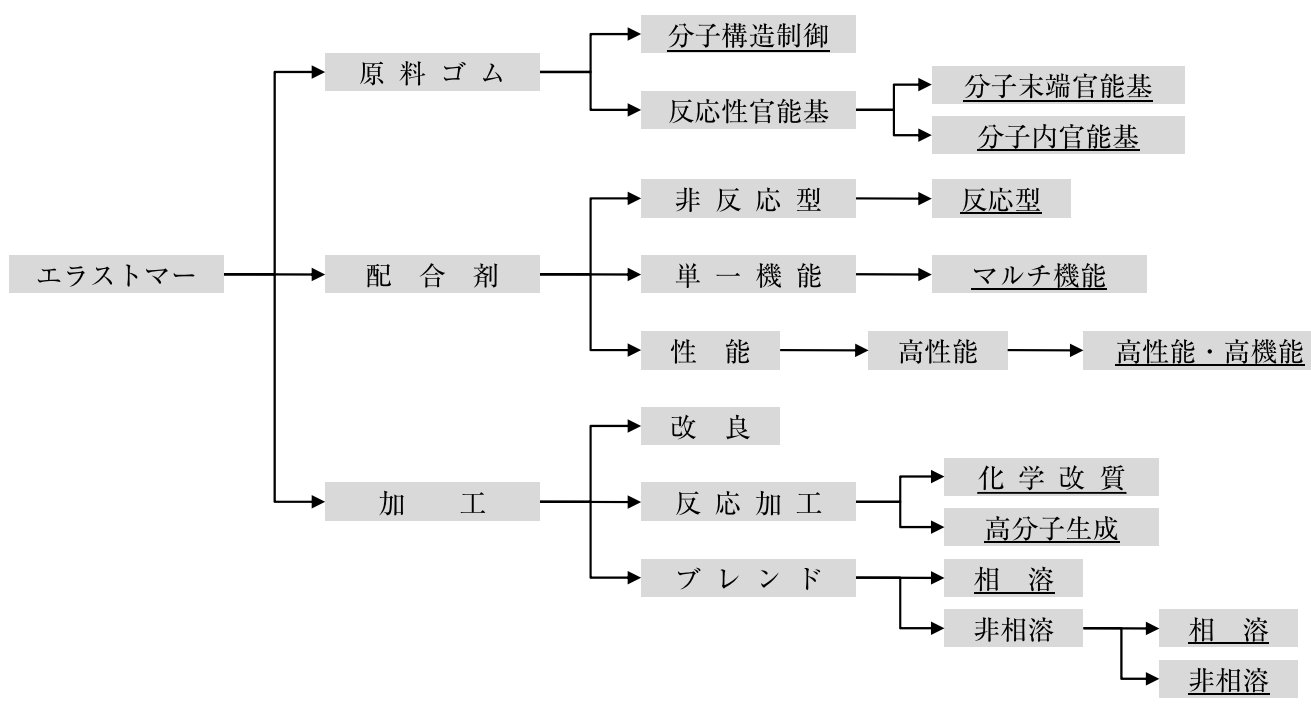

